\title{
Preoperatively elevated RDW-SD and RDW-CV predict favorable survival in intrahepatic cholangiocarcinoma patients after curative resection
}

Xingchen $\mathrm{Li}^{\dagger}$, Qichen Chen ${ }^{\dagger}$, Xinyu Bi, Jianjun Zhao, Zhiyu Li, Jianguo Zhou, Zhen Huang, Yefan Zhang, Rui Mao, Hong Zhao and Jianqiang Cai

\begin{abstract}
Background: Recent studies suggest red blood cell distribution width (RDW) was a prognostic factor in various types of cancer patients, although the results are controversial. The objective of this study was to investigate the significance of RDW in patients with intrahepatic cholangiocarcinoma (ICC) after radical resection.

Method: The relationship between the preoperative serum RDW value and clinic pathological characteristics was analyzed in 157 ICC patients between January 2012 and June 2018 who underwent curative resection. X-tile software was used to determine $40.2 \mathrm{fl}, 12.6 \%$ as the optimal cut-off value for RDW-SD and RDW-CV respectively. 153 patients were classified into the low RDW-SD $(\leq 40.2, n=53)$ group and the high RDW-SD $(>40.2, n=104)$ group, low RDW-CV $(\leq 12.6, n=94)$ group and the high RDW-CV $(>12.6, n=63)$. Based on the RDW-SD combined with RDW-CV (SCC), classified into $\mathrm{SCC}=0,1$ and 2 group. Kaplan-Meier survival analysis and Cox proportional hazard models were used to examine the effect of RDW on survival.

Results: Kaplan-Meier curve analysis showed that Patients with RDW-SD $>40.2$ were significantly associated with better OS ( $P=0.004$, median OS: 68.0 months versus 17.0 months). Patients with RDW-CV > 12.6 were significantly associated with better OS ( $p=0.030$, median OS: not reach versus 22.0 months). Compared with a SCC $=0$ or $S C C=1, S C C=2$ was significantly associated with better $O S$ ( $p<0.001$, median OS: not reach versus 33.0 months versus 16, respectively). In the multivariate analysis, $\mathrm{RDW}-\mathrm{SD}>40.2 \mathrm{fl}(\mathrm{HR}=0.446,95 \% \mathrm{Cl}: 0.262-0.760, \mathrm{p}=0.003)$, RDW-CV > 12.6\% ( $H R=0.425,95 \% C l: 0.230-0.783, p=0.006), S C C=2(H R=0.270,95 \% C l: 0.133-0.549, p<0.001)$ were associated with favorable OS. The multivariate analysis showed RDW-SD, RDW-CV and SCC level were not independent prognostic factors for DFS.
\end{abstract}

Conclusions: Preoperative low levels of RDW are associated with poor survival in ICC after curative resection. This provides a new way for predicting the prognosis of ICC patients and more targeted intervention measures.

Keywords: Intrahepatic cholangiocarcinoma, Liver resection, RDW, Prognosis

*Correspondence: caijianqiang@cicams.ac.cn

${ }^{\dagger}$ Xingchen Li and Qichen Chen equally to this work

Department of Hepatobiliary Surgery, National Cancer Center/National

Clinical Research Center for Cancer/Cancer Hospital, Chinese Academy

of Medical Sciences and Peking Union Medical College, No. 17 Nanli,

Panjiayuan, Chaoyang District, Beijing, China

\section{Background}

Intrahepatic cholangiocarcinoma (ICC) is a relatively rare type of primary liver cancer that arises from the intrahepatic bile duct epithelium and accounts for $75 \%$ of primary liver carcinomas, the incidence of which is increasing year by year [1]. The only curative treatment is 
surgical resection. Even when potentially curative resections are achieved, the 5-year survival rate after resection is only 8 to $47 \%$ because these tumors have a high degree of malignancy, insidious onset and early subclinical changes and are very difficult to discover. Clear margins during resection are emphasized as the most important factor for good local control and a favorable prognosis; in addition, lymph node metastasis is also one of the most significant prognostic factors for survival in ICC [2]. Surgery requires radical resection with appropriate lymph node resection. The prognosis of patients is closely related to whether radical resection can be performed, but the radical resection rate of ICC is only 15 to $20 \%$, far lower than the surgical resection rate of $70 \%$ for distal cholangiocarcinoma. Even though patients with ICC who undergo extended resection still have a poor prognosis, this is closely related to the high incidence of local recurrence and distant metastasis [3]. To date, no systemic adjuvant therapy has improved overall survival (OS), despite the increased research effort and active clinical trials investigating a variety of drugs [4]. We should attach great importance to this kind of malignant disease in the clinic.

Although the reasons for the high recurrence rate in ICC are complicated, inflammation plays an important role in the malignant progression and metastasis of ICC $[5,6]$. In addition, there is substantial evidence that systemic inflammation predicts survival and recurrence of ICC after resection [7]. Some studies have shown that systemic inflammatory markers of serum parameters, including platelet count (PLT), hemoglobin, neutrophillymphocyte ratio (NLR) and platelet-lymphocyte ratio (PLR), can predict the survival of a variety of human cancers [8-12]. Red cell volume distribution width (RDW) is a conventional biomarker of erythrocyte volume variability and an indicator of homeostasis [13]. Recent evidence suggests that unequal erythrocyte action is involved in a variety of human diseases, such as cardiovascular disease $[14,15]$ and cancer $[16,17]$. There is some evidence that high RDW levels are a negative prognostic indicator for these diseases, and inflammation is the mechanism leading to these high levels [13]. There is increasing evidence that elevated RDW levels are also associated with poor prognosis in a variety of cancers, including hepatocellular carcinoma (HCC) $[18,19]$, esophageal cancer [20, 21], lung cancer [22] and hematological malignancies [23]. However, a review of the previous related literature shows some research limitations. Multivariate analysis showed that preoperative RDW is not an independent prognostic indicator of OS in gastric adenocarcinoma patients [24]. Due to the inevitable heterogeneity of the study samples, the prognostic effects of RDW have not been fully investigated. The predictive value of RDW in
ICC patients has not been demonstrated. The purpose of this study was to evaluate the relationship between RDW and clinical outcomes in ICC patients.

\section{Methods \\ Patients}

The clinical date of 157 cases with ICC from our hospital between January 2012 and June 2018 were collected and analyzed retrospectively. The inclusion criteria were as follows: (1) complete (R0) resection of liver cancer and histopathological diagnosis of ICC; and (2) none of these patients had previous malignant disease. The exclusion criteria were as follows: (1) patients with clinical or pathologic distant metastasis; (2) perioperative mortality; (3) no follow-up data; and (4) pretreatment diseases associated with RDW levels (thrombosis, sepsis, cardiovascular disease, etc.). The Ethics Committee of the Cancer Hospital, Chinese Academy of Medical Sciences approved the study, and the requirement for informed consent was waived.

Major resections were defined as a resection of more than two segments, and other resection was described as a minor resection. Serum red blood cell distribution width-standard deviation (RDW-SD) levels and red blood cell distribution width- coefficient of variation (RDW$\mathrm{CV})$ levels were measured within 1 week before surgery. Blood samples for the evaluation of serum RDW-SD levels (37.0-57.0 fl) and RDW-SD levels (111.6-14.6 fl) were obtained by using peripheral venous punctures. The RDW-SD combined with RDW-CV (SCC) was established to analyses the prognostic value of survival. The SCC was scored as 0 (decreased RDW-SD levels with decreased RDW-CV), 2 (elevated RDW-SD levels with elevated RDW-SD levels), or 1 (all other combinations). Each postoperative complication was described as a severity grade using the Clavien-Dindo classification system (I-V). Major complications were classified as Clavien-Dindo III-V. If multiple postoperative complications occurred in one patient, the higher grade was used.

\section{Follow-up}

Patients were required to visit the clinics 1 month after surgery. Then, the patients were required to visit the clinics every 3 months for the next 2 years, every 6 months for the following 3 years, and once annually thereafter. Patients received postoperative serum tumor markers (carbohydrate antigen 19-9 [CA19-9], carcinoembryonic antigen [CEA] and alpha fetoprotein $[\mathrm{AFP}])$ measurements and magnetic resonance imaging (MRI) or computed tomography (CT) at every visit time. Recurrence was detected by the tumor markers level and imaging. The patients' follow-up adjuvant treatment was chosen based on the first review, which 
included assessments of pathological stage, microvascular invasion (MVI) and other high-risk relapse factors. During the follow-up review process, when recurrence was confirmed, salvage treatment including reoperation, percutaneous ablation or transarterial chemoembolization (TACE) was performed as needed. In this study, the examination data of the patients were extracted from the hospital medical records system, and the patients were followed up by telephone. The deadline for follow-up was the date of the last followup or death.

\section{Statistical analysis}

The clinicopathologic characteristics were compared using the $\mathrm{X}^{2}$ and Mann-Whitney $\mathrm{U}$ tests, as appropriate. For testing markers (albumin [ALB], total bilirubin [TBIL], aspartate aminotransferase [AST], alanine aminotransferase [ALT], et al.), the upper limit of normal value was defined as cutoff value; for operation time and intraoperative blood loss, the median was defined as cutoff value. X-tile [25] analysis was implemented to investigate the optimal cut-off point of RDW-SD and $\mathrm{RDW}-\mathrm{CV}$. The X-tile plots are created by dividing marker data into two populations: low and large. All possible divisions of the marker data are assessed. Associations can be calculated at each division by a variety of standard statistical tests, including the logrank test for survival and means tests for associations between other marker data. Alternatively, the program can select the optimal division of the data by selecting the highest $\mathrm{X}^{2}$ value. OS was defined as the interval between the date of resection and the date of death or the last follow-up, and disease-free survival (DFS) was defined as the duration from resection to tumor progression or the last follow-up. This study used the Kaplan-Meier method to estimate DFS and OS and statistically compared the data by log-rank test. A forward LR Cox regression model was created to identify prognostic factors that influence OS and DFS. Variables with $\mathrm{P}<0.10$ in the univariable analysis were included in the multivariable analysis. The RDW-SD level and RDW-CV level exhibited collinearity $(\mathrm{p}<0.001)$. To prevent collinearity, RDW-SD was included in the multivariate analysis of Model 1 (exclude of RDW-CV), and RDW-CV was included in the multivariate analysis of Model 2 (exclude of RDW-SD). Because the SCC score was based on RDW-SD and RDW-CV, the multivariate analysis of Model 3 included SCC score and factors with a $\mathrm{p}<0.1$ in the univariate analysis exclude of the RDW-SD and RDW-CV. All analyses were performed using SPSS, version 22 software (Armonk, NY, USA). $\mathrm{p}<0.05$ was considered statistically significant.

\section{Results}

\section{Clinicopathological characteristics}

The median age of all 157 patients was 58.00 (IQR: $51.50-64.00)$ years and most patients (55.4\%) were male. The proportion of patients with positive serum hepatitis B surface antigen ( $\mathrm{HBsAg}$ ) was $21.7 \%$. The proportion of patients with lesions in the central liver was $49.7 \%$. The median diameter of the largest ICC lesion was 5.5 (IQR $3.8-7.0) \mathrm{cm}$, and $54.8 \%$ of patients had a lesion larger than $5 \mathrm{~cm}$. A total of $19.1 \%$ of patients had multiple tumors and $26.8 \%$ of the patients had LNM. Ninety one patients $(58.0 \%)$ were observed with poorly differentiated tumors.

The preoperative clinical laboratory tests were as follows: tumor markers: preoperative CA19-9>27 U/ $\mathrm{mL}$ (52.4\%), preoperative CEA $>5 \mathrm{ng} / \mathrm{mL}$ (22.3\%); liver function markers: $\mathrm{ALB} \geq 40 \mathrm{~g} / \mathrm{L} \quad(79.0 \%)$, TBIL $>21 \mu \mathrm{mol} / \mathrm{L}(11.5 \%)$, AST $>40 \mathrm{U} / \mathrm{L}$ (9.6\%), and ALT $>50 \mathrm{U} / \mathrm{L}$ (8.9\%). The median RDW-SD level was $41.1 \mathrm{fl}$ (IQR 39.7-43.3). The median RDW-CV level was $12.4 \%$ (IQR 12.0-13.1). A total of 58.6\% (92/157) of the patients have postoperative complications, including 33 major complications and 59 minor complications. Seventy-nine patients had an operation time $\geq 230 \mathrm{~min}$, and $49.0 \%$ patients had blood loss $\geq 300 \mathrm{~mL}$. Ten patients $(6.4 \%)$ received preoperative therapy and 66 patients $(42.0 \%)$ received postoperative therapy. The detailed clinicopathologic parameters of patients are in Table 1.

\section{Relationships among RDW-SD, RDW-CV, SCC and clinicopathological characteristics}

X-tile software was used to determine $40.2 \mathrm{fl}$ and $12.6 \%$ as the optimal cut-off values for RDW-SD and RDW$\mathrm{CV}$, respectively. Based on RDW-SD levels, 157 patients were classified into a low RDW-SD $(\leq 40.2, \mathrm{n}=53)$ group and high RDW-SD $(>40.2, \mathrm{n}=104)$ group. Based on RDW-CV levels, 157 patients were classified into a low RDW-CV $(\leq 12.6, \mathrm{n}=94)$ group and high RDW-CV $(>12.6, \mathrm{n}=63)$ group. Based on the RDW-SD combined with RDW-CV (SCC), 46 patients were classified into the $\mathrm{SCC}=0$ group, 55 patients were classified into the $\mathrm{SCC}=1$ group, and 56 patients were classified into the $\mathrm{SCC}=2$ group.

The high RDW-SD group had more patients with an ASA status of $1-2 \quad(\mathrm{p}=0.027)$ and operation time $<230$ min $(\mathrm{p}=0.027)$ than the low RDW-SD group. The high RDW-CV group had more patients with nonliver cirrhosis $(\mathrm{p}=0.020), \mathrm{T} 1-\mathrm{T} 2$ stage disease $(\mathrm{p}=0.005)$ and $\mathrm{TBIL} \leq 21 \mu \mathrm{mol} / \mathrm{L} \quad(\mathrm{p}=0.015)$. The patients with $\mathrm{SCC}=0$ was associated with an age $<60$ years $(\mathrm{p}=0.029)$ (Table 1). 
Table 1 Patient and tumour characteristics

\begin{tabular}{|c|c|c|c|c|}
\hline \multirow[t]{2}{*}{ Item } & \multirow[t]{2}{*}{$\begin{array}{l}\text { All patients } \\
(n=157)(\%)\end{array}$} & \multirow{2}{*}{$\begin{array}{l}\text { RDW-SD }>40.2 \mathrm{fl} \mathrm{VS} \\
\text { RDW-SD } \leq 40.2 \mathrm{fl} \\
\mathrm{p}\end{array}$} & \multirow{2}{*}{$\begin{array}{l}\text { RDW-CV }>12.6 \% \text { VS } \\
\text { RDW-CV } \leq 12.6 \% \\
p\end{array}$} & \multirow{2}{*}{$\begin{array}{l}\mathrm{SCC}=0 \mathrm{VS} \\
\mathrm{SCC}=1 \mathrm{VS} \\
\mathrm{SCC}=2 \\
\mathrm{p}\end{array}$} \\
\hline & & & & \\
\hline Age $\geq 60$ years & $70(44.6)$ & 0.056 & 0.494 & 0.029 \\
\hline Male & $87(55.4)$ & 0.900 & 0.977 & 0.882 \\
\hline $\mathrm{BMI} \geq 24 \mathrm{~kg} / \mathrm{m}^{2}$ & $94(60.3)$ & 0.355 & 0.187 & 0.392 \\
\hline ASA score 3-4 & $13(8.3)$ & 0.027 & 0.190 & 0.099 \\
\hline Cirrhosis & $57(36.3)$ & 0.790 & 0.020 & 0.279 \\
\hline $\operatorname{HBsAg}(+)$ & $34(21.7)$ & 0.294 & 0.758 & 0.906 \\
\hline T3-T4 stage & $33(21.0)$ & 0.768 & 0.005 & 0.008 \\
\hline Lymphnode metastasis & $42(26.8)$ & 0.971 & 0.736 & 0.781 \\
\hline Tumor size $\geq 5 \mathrm{~cm}$ & $86(54.8)$ & 0.314 & 0.873 & 0.854 \\
\hline Multiple tumors & $30(19.1)$ & 0.357 & 0.213 & 0.067 \\
\hline Tumor location (Central tumor) & $78(49.7)$ & 0.573 & 0.580 & 0.994 \\
\hline Tumor location (right lobe) & $77(49.0)$ & 0.970 & 0.785 & 0.721 \\
\hline Poorly differentiation & $91(58.0)$ & 0.089 & 0.515 & 0.275 \\
\hline Preoperative CA19-9>27 U/mL & $82(52.2)$ & 0.333 & 0.279 & 0.374 \\
\hline Preoperative CEA > $5 \mathrm{ng} / \mathrm{mL}$ & $35(22.3)$ & 0.174 & 0.142 & 0.202 \\
\hline RDW-SD $>40.2 \mathrm{fl}$ & $104(66.2)$ & - & $<0.001$ & - \\
\hline RDW-CV > 12.6\% & $63(40.1)$ & $<0.001$ & - & - \\
\hline $\mathrm{SCC}=0$ & $46(29.3)$ & - & - & - \\
\hline $\mathrm{SCC}=1$ & $55(35.0)$ & - & - & - \\
\hline $\mathrm{SCC}=2$ & $56(35.7)$ & - & - & - \\
\hline$A L B \geq 40 \mathrm{~g} / \mathrm{L}$ & $124(79.0)$ & 0.375 & 0.133 & 0.283 \\
\hline $\mathrm{TBIL}>21 \mathrm{umol} / \mathrm{L}$ & $18(11.5)$ & 0.968 & 0.015 & 0.169 \\
\hline $\mathrm{AST}>40 \mathrm{U} / \mathrm{L}$ & $15(9.6)$ & 0.591 & 0.587 & 0.179 \\
\hline $\mathrm{ALT}>50 \mathrm{U} / \mathrm{L}$ & $14(8.9)$ & 0.053 & 0.724 & 0.024 \\
\hline Operation time $\geq 230 \mathrm{~min}$ & $79(50.3)$ & 0.027 & 0.896 & 0.052 \\
\hline Blood loss $\geq 300 \mathrm{ml}$ & $77(49.0)$ & 0.921 & 0.297 & 0.827 \\
\hline Major liver resection & $113(72.0)$ & 0.667 & 0.548 & 0.812 \\
\hline Post-operative complications & $92(58.6)$ & 0.164 & 0.720 & 0.353 \\
\hline Preoperative therapy & $10(6.4)$ & 0.101 & 0.008 & 0.010 \\
\hline Adjuvant therapy & $66(42.0)$ & 0.924 & 0.407 & 0.105 \\
\hline
\end{tabular}

Prognostic value of RDW-SD, RDW-CV and SCC for survival The median follow-up time was 33.00 months. The median OS and median DFS were 28.00 months (95\% CI: 12.9-43.1) and 10.00 months (95\% CI: 7.2-12.8), respectively. One hundred and nine patients (69.4\%) underwent recurrence, and 73 patients (46.5\%) died. The 1-, 3- and 5 -year progression-free survival rates were $41.8 \%$, 29.5\%, and $20.9 \%$, respectively. The $1-, 3$ - and 5-year survival rates were $72.9 \%, 46.0 \%$ and $41.1 \%$, respectively.

Kaplan-Meier curve analysis revealed that patients with RDW-SD $>40.2$ were significantly associated with better OS $(p=0.004$, median OS: 68.0 months versus 17.0 months $)$ and better DFS $(p=0.047$, median DFS: 11.0 months versus 7.0) than those with low RDW-SD values (Fig. 1). Patients with RDW-CV> 12.6 were significantly associated with better OS $(\mathrm{p}=0.030$, median OS: not reached versus 22.0 months) and had an equivalent DFS ( $p=0.579$, median DFS: 11.0 months versus 10.0) than those with low RDW-CV values (Fig. 2). Compared with patients with $\mathrm{SCC}=0$ or $\mathrm{SCC}=1$, patients with $\mathrm{SCC}=2$ were significantly associated with better OS $(p<0.001$, median OS: did not reach versus 33.0 months versus 16, respectively), but all three SCC values had an equivalent DFS ( $\mathrm{p}=0.247$, median DFS: 11.0 months versus 12.0 months versus 7.0 months, respectively) (Fig. 3).

\section{OS analysis}

In the univariate analysis, T3-T4 stage $(\mathrm{p}<0.001)$, lymph node metastasis $(\mathrm{p}<0.001)$, noncentral tumor $(\mathrm{p}=0.027)$, poor differentiation $(\mathrm{p}=0.044)$, preoperative $C E A>5 \mathrm{ng} / \mathrm{mL}(\mathrm{p}=0.001), \mathrm{RDW}-\mathrm{SD} \leq 40.2 \mathrm{fl}$ 

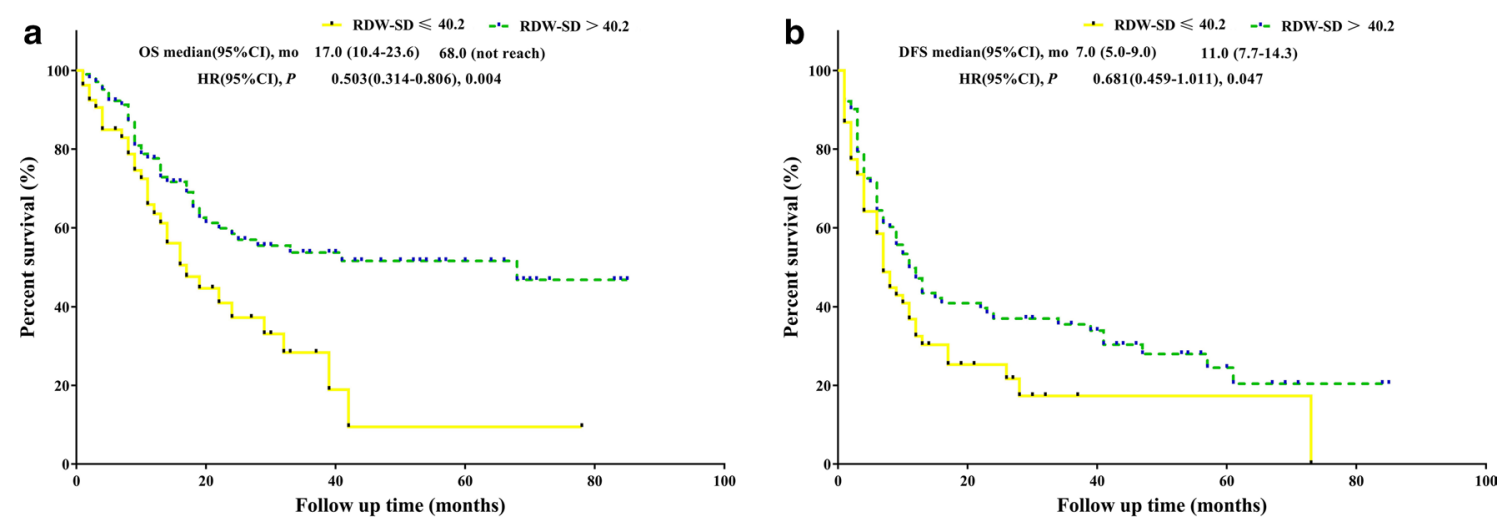

Fig. 1 a OS analysis of RDW-SD > 40.2 fl versus RDW-SD $\leq 40.2$ fl. b DFS analysis of RDW-SD $>40.2 \mathrm{fl}$ versus RDW-SD $\leq 40.2 \mathrm{fl}$
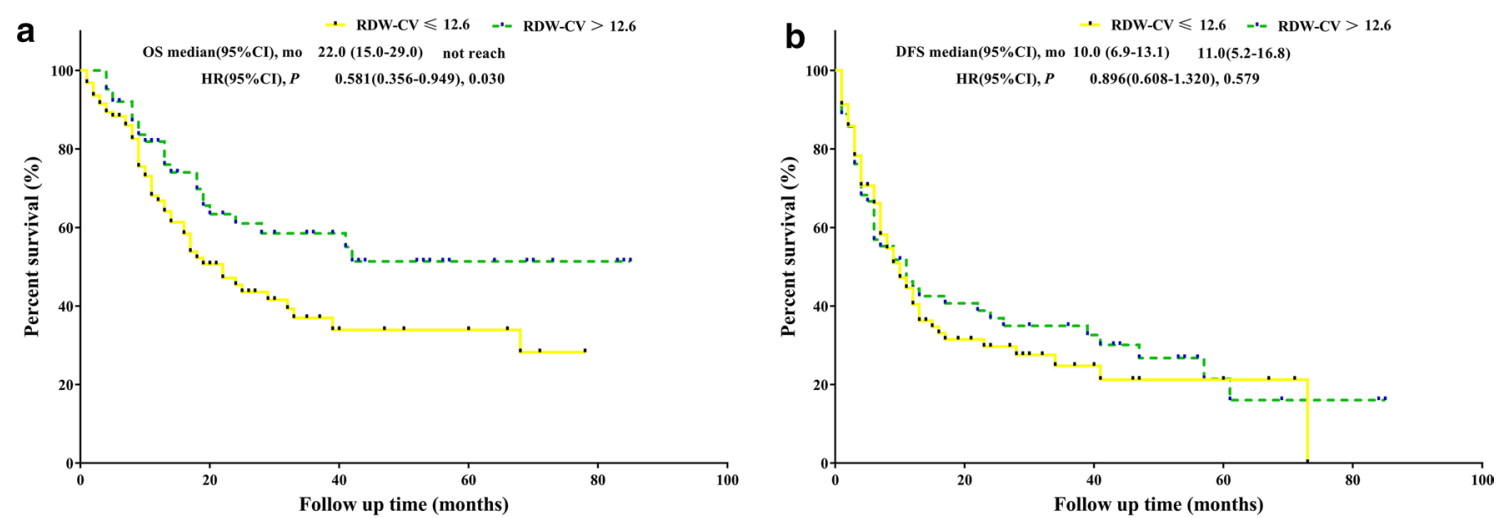

Fig. 2 a OS analysis of RDW-CV > 12.6\% versus RDW-CV $\leq 12.6 \%$ b DFS analysis of RDW-CV $>12.6 \%$ versus RDW-CV $\leq 12.6 \%$
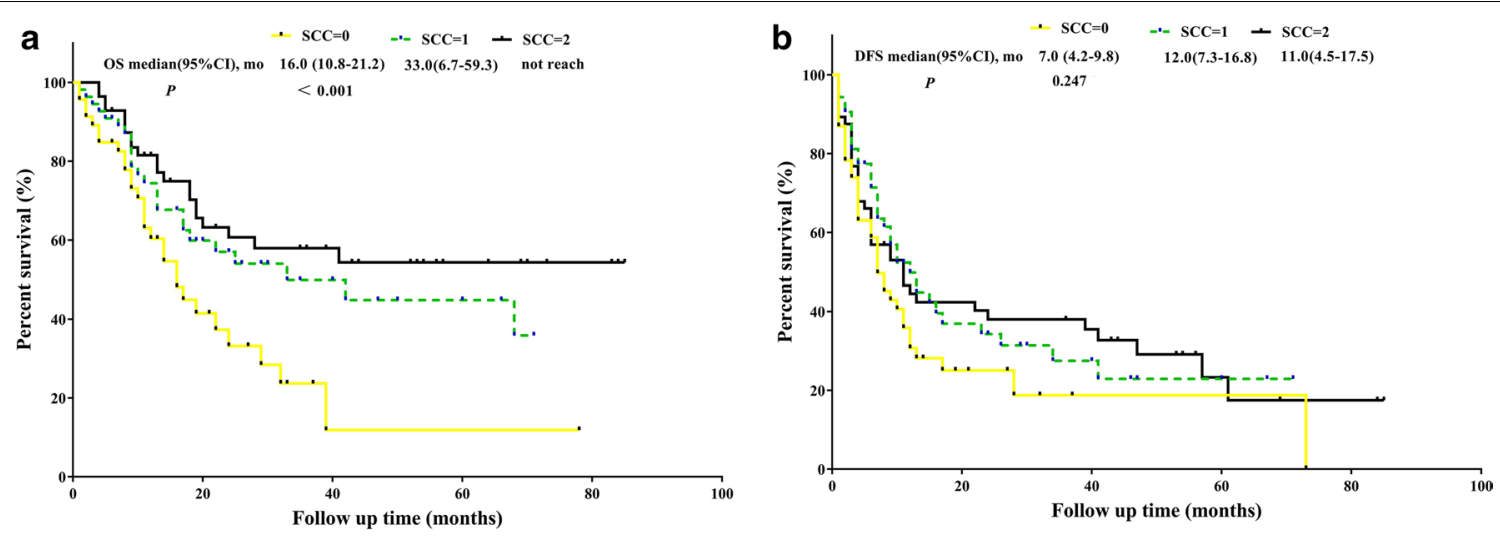

Fig. 3 a OS analysis of SCC $=0$ versus SCC $=1$ versus SCC $=2$ b DFS analysis of SCC $=0$ versus $S C C=1$ versus SCC $=2$

$(\mathrm{p}=0.004), \quad$ RDW $-\mathrm{CV} \leq 12.6 \% \quad(\mathrm{p}=0.030)$, $\mathrm{ALB}<40 \mathrm{~g} / \mathrm{L} \quad(\mathrm{p}=0.048)$, operation time $\geq 230 \mathrm{~min}$ $(\mathrm{p}=0.015)$, blood loss $\geq 300 \mathrm{ml} \quad(\mathrm{p}=0.030)$ and decreased SCC score $(\mathrm{p}=0.007)$ were all associated with shorter OS (Table 2). In the multivariate analysis of model 1, RDW-SD $>40.2 \mathrm{fl}(\mathrm{HR}=0.446,95 \% \mathrm{CI}$ : $0.262-0.760, \mathrm{p}=0.003)$, central tumor $(\mathrm{HR}=0.367$, 95\% CI: $0.210-0.641, \mathrm{p}<0.001)$, and adjuvant therapy $(\mathrm{HR}=0.423,95 \% \mathrm{CI}: 0.232-0.774, \mathrm{p}=0.005)$ were significantly associated with favorable OS. In the 
Table 2 Prognostic factors for OS for ICC patients in univariate analysis

\begin{tabular}{|c|c|c|c|c|c|}
\hline \multirow[t]{2}{*}{ Factor } & \multicolumn{2}{|l|}{ Univariate analysis } & \multirow[t]{2}{*}{ Factor } & \multicolumn{2}{|l|}{ Univariate analysis } \\
\hline & $\mathrm{HR}(95 \% \mathrm{Cl})$ & Value $p$ & & $\mathrm{HR}(95 \% \mathrm{Cl})$ & Value $p$ \\
\hline Age $\geq 60$ years & $0.778(0.483-1.251)$ & 0.300 & Preoperative CEA $>5 \mathrm{ng} / \mathrm{mL}$ & $2.365(1.429-3.913)$ & 0.001 \\
\hline Male & $1.418(0.887-2.267)$ & 0.144 & RDW-SD $>40.2 \mathrm{fl}$ & $0.503(0.314-0.806)$ & 0.004 \\
\hline $\mathrm{BMI} \geq 24 \mathrm{~kg} / \mathrm{m}^{2}$ & $1.356(0.843-2.182)$ & 0.209 & RDW-CV $>12.6 \%$ & $0.581(0.356-0.949)$ & 0.030 \\
\hline ASA score 3-4 & $0.970(0.420-2.238)$ & 0.943 & $A L B \geq 40 \mathrm{~g} / \mathrm{L}$ & $0.600(0.361-0.996)$ & 0.048 \\
\hline Cirrhosis & $0.929(0.575-1.500)$ & 0.763 & $\mathrm{TBIL}>21 \mathrm{umol} / \mathrm{L}$ & $0.913(0.438-1.904)$ & 0.808 \\
\hline $\operatorname{HBsAg}(+)$ & $0.754(0.420-1.351)$ & 0.343 & $\mathrm{AST}>40 \mathrm{U} / \mathrm{L}$ & $1.773(0.909-3.458)$ & 0.093 \\
\hline T3-T4 stage & $2.381(.431-3.962)$ & 0.001 & $\mathrm{ALT}>50 \mathrm{U} / \mathrm{L}$ & $1.814(0.899-3.660)$ & 0.096 \\
\hline Lymphnode metastasis & & $<0.001$ & Operation time $\geq 230 \mathrm{~min}^{\mathrm{b}}$ & $1.785(1.118-2.851)$ & 0.015 \\
\hline Undissected lymph node & Reference & - & Blood loss $\geq 300 \mathrm{ml}^{\mathrm{b}}$ & $1.713(1.053-2.788)$ & 0.030 \\
\hline Negative lymph node & $0.742(0.414-1.331)$ & 0.317 & Major liver resection & $1.419(0.832-2.419)$ & 0.198 \\
\hline Positive lymph node & $2.808(1.554-5.072)$ & 0.001 & Post-operative complications & $1.027(0.640-1.647)$ & 0.913 \\
\hline Tumor size $\geq 5 \mathrm{~cm}$ & $1.529(0.956-2.448)$ & 0.077 & Preoperative therapy & $0.648(0.204-2.060)$ & 0.462 \\
\hline Multiple tumors & $1.657(0.955-2.874)$ & 0.073 & Adjuvant therapy & $0.663(0.410-1.072)$ & 0.094 \\
\hline Tumor location (central tumor) & $0.587(0.366-0.941)$ & 0.027 & The prognostic value on SCC score & & 0.007 \\
\hline Tumor location (right lobe) & $0.858(0.588-1.252)$ & 0.427 & $\mathrm{SCC}=0$ & Reference & - \\
\hline Poor differentiation & $1.667(1.013-2.743)$ & 0.044 & $\mathrm{SCC}=1$ & $0.554(0.320-0.961)$ & 0.035 \\
\hline Preoperative CA19-9> $27 \mathrm{U} / \mathrm{mL}$ & $1.332(0.763-2.327)$ & 0.313 & $\mathrm{SCC}=2$ & $0.411(0.231-0.730)$ & 0.002 \\
\hline
\end{tabular}

multivariate analysis of model 2, RDW-CV $>12.6 \%$ $(\mathrm{HR}=0.425,95 \% \mathrm{CI}: 0.230-0.783, \mathrm{p}=0.006)$, central tumor $(\mathrm{HR}=0.307,95 \% \mathrm{CI}: 0.171-0.552, \mathrm{p}<0.001)$, and adjuvant therapy ( $\mathrm{HR}=0.481,95 \% \mathrm{CI}$ : $0.264-$ $0.876, p=0.017)$ were significantly associated with favorable OS. In the multivariate analysis of model 3, the multivariate analysis showed that compared with $\mathrm{SCC}=0, \mathrm{SCC}=1 \quad(\mathrm{HR}=0.296,95 \% \mathrm{CI}:$ 0.153-0.571, $\mathrm{p}<0.001)$ and $\mathrm{SCC}=2(\mathrm{HR}=0.270,95 \% \mathrm{CI}: 0.133-$ $0.549, \mathrm{p}<0.001)$ were associated with favorable OS (Table 3).

\section{DFS analysis}

In the univariate analysis, RDW-SD $\leq 40.2 \mathrm{fl}$ $(\mathrm{p}=0.047), \mathrm{T} 3-\mathrm{T} 4$ stage $(\mathrm{p}=0.017)$, lymph node metastasis $(p<0.001)$, multiple tumors $(p=0.018)$, preoperative CEA $>5 \mathrm{ng} / \mathrm{mL}(\mathrm{p}<0.001), \mathrm{ALT}>50 \mathrm{U} / \mathrm{L}$ $(\mathrm{p}=0.019)$ and blood loss $\geq 300 \mathrm{~mL}(\mathrm{p}=0.008)$ were associated with worse DFS. RDW-CV $(\mathrm{p}=0.579)$ and SCC score $(\mathrm{p}=0.247)$ were not associated with DFS (Table 4). The multivariate analysis showed that RDWSD level was not an independent prognostic factor, and positive lymph node $(\mathrm{HR}=2.566,95 \% \mathrm{CI}: 1.388-4.746$, $\mathrm{p}=0.003)$, multiple tumors $(\mathrm{HR}=2.181,95 \% \mathrm{CI}$ : 1.296-3.671, $\mathrm{p}=0.003)$ and preoperative CEA $>5 \mathrm{ng} /$ $\mathrm{mL}(\mathrm{HR}=1.750,95 \% \mathrm{CI}: 1.045-2.929, \mathrm{p}=0.033)$ were independent predictors for the unfavourable OS.

\section{Discussion}

To the best of knowledge, this study is the first to use X-tile software to objectively identify the optimal cutoff point values of RDW-SD and RDW-CV for predicting survival. We discussed the relationship between preoperative RDW values and postoperative prognosis in ICC patients on the premise of excluding other diseases that affect RDW value. Our results indicated that patients with higher RDW values had better prognoses.

RDW level is an marker of the degree of erythrocyte morphology imbalance in the blood, and it reflects the heterogeneity of erythrocyte volume [26]. RDW level may change as a result of blood diseases, infectious diseases, and even cancer $[27,28]$. Additionally, studies have revealed that RDW level was an independent risk factor for survival in patients with colorectal cancer and bladder cancer [29-31]. RDW values are reflected in coefficient of variation of red cell volume distribution width (RDW$\mathrm{CV}$ ) and standard deviation of red cell volume distribution width ((RDW-SD) levels. RDW-SD and RDW-CV were generally used to evaluate the RDW level in clinics. In our study, patients with high RDW-SD or RDW-CV were significantly associated with better OS. We used SCC as the combined index of RDW-SD and RDW-CV, and compared with $\mathrm{SCC}=0$ or $\mathrm{SCC}=1, \mathrm{SCC}=2$ was significantly associated with better $\mathrm{OS}$ and had an equivalent DFS. SCC is a combined indicator, so the differences between the three classifications further strengthen their 
Table 3 Prognostic factors for OS for ICC patients in multivariate analysis

\begin{tabular}{|c|c|c|c|c|c|c|c|c|c|}
\hline \multirow[t]{3}{*}{ Factor } & \multicolumn{4}{|c|}{ Multivariate analysis ${ }^{a}$} & \multirow[t]{3}{*}{ Factor } & \multicolumn{4}{|c|}{ Multivariate analysis ${ }^{\mathbf{a}}$} \\
\hline & \multicolumn{2}{|l|}{ Model 1} & \multicolumn{2}{|l|}{ Model 2} & & \multicolumn{2}{|l|}{ Model 1} & \multicolumn{2}{|l|}{ Model 2} \\
\hline & $\mathrm{HR}(95 \% \mathrm{Cl})$ & Value $p$ & $\mathrm{HR}(95 \% \mathrm{Cl})$ & Value $p$ & & $\mathrm{HR}(95 \% \mathrm{Cl})$ & Value $P$ & $\mathrm{HR}(95 \% \mathrm{Cl})$ & Value $p$ \\
\hline Age $\geq 60$ years & - & - & - & - & RDW-SD > $40.2 \mathrm{fl}$ & $\begin{array}{l}0.446(0.262- \\
0.760)\end{array}$ & 0.003 & - & - \\
\hline Male & - & - & & - & RDW-CV>12.6\% & - & - & $\begin{array}{l}0.425(0.230- \\
0.783)\end{array}$ & 0.006 \\
\hline $\mathrm{BMI} \geq 24 \mathrm{~kg} / \mathrm{m}^{2}$ & - & - & - & - & $A L B \geq 40 \mathrm{~g} / \mathrm{L}$ & $\begin{array}{l}0.472(0.257- \\
0.866)\end{array}$ & 0.015 & $\begin{array}{l}0.511(0.269- \\
0.974)\end{array}$ & 0.041 \\
\hline ASA score 3-4 & - & - & - & - & TBIL > $21 \mathrm{umol} / \mathrm{L}$ & - & - & - & - \\
\hline Cirrhosis & - & - & - & - & $\mathrm{AST}>40 \mathrm{U} / \mathrm{L}$ & - & - & - & - \\
\hline HBsAg (+) & - & - & - & - & $\mathrm{ALT}>50 \mathrm{U} / \mathrm{L}$ & - & - & $\begin{array}{l}2.332(0.984- \\
5.528)\end{array}$ & 0.055 \\
\hline T3-T4 stage & - & - & - & - & $\begin{array}{l}\text { Operation } \\
\text { time } \geq 230 \\
\min ^{b}\end{array}$ & $\begin{array}{l}1.894(1.097- \\
3.270)\end{array}$ & 0.019 & $\begin{array}{l}1.804(1.030- \\
3.161)\end{array}$ & 0.039 \\
\hline $\begin{array}{l}\text { Lymphnode } \\
\text { metastasis }\end{array}$ & - & $<0.001$ & - & $<0.001$ & $\begin{array}{l}\text { Blood loss } \geq 300 \\
\mathrm{ml}^{\mathrm{b}}\end{array}$ & - & - & - & - \\
\hline $\begin{array}{l}\text { Undissected } \\
\text { lymph node }\end{array}$ & Reference & & Reference & & $\begin{array}{l}\text { Major liver } \\
\text { resection }\end{array}$ & - & - & - & - \\
\hline $\begin{array}{l}\text { Negative lymph } \\
\text { node }\end{array}$ & $\begin{array}{l}1.160(0.581- \\
2.318)\end{array}$ & 0.674 & $\begin{array}{l}1.226(0.595- \\
2.526)\end{array}$ & 0.580 & $\begin{array}{l}\text { Post-operative } \\
\text { Complications }\end{array}$ & - & - & - & - \\
\hline $\begin{array}{l}\text { Positive lymph } \\
\text { node }\end{array}$ & $\begin{array}{l}3.715(1.721- \\
8.019)\end{array}$ & 0.001 & $\begin{array}{l}4.394(1.950- \\
9.900)\end{array}$ & $<0.001$ & $\begin{array}{l}\text { Preoperative } \\
\text { therapy }\end{array}$ & - & - & - & - \\
\hline $\begin{array}{l}\text { Tumor } \\
\quad \text { size } \geq 5 \mathrm{~cm}\end{array}$ & - & - & $\begin{array}{l}2.041(1.134- \\
3.673)\end{array}$ & 0.017 & $\begin{array}{l}\text { Adjuvant } \\
\text { therapy }\end{array}$ & $\begin{array}{l}0.423(0.232- \\
0.774)\end{array}$ & 0.005 & $\begin{array}{l}0.481(0.264- \\
0.876)\end{array}$ & 0.017 \\
\hline Multiple tumors & - & - & - & - & & Multivariate an & sis ${ }^{c}$ (Model & & \\
\hline $\begin{array}{l}\text { Tumor location } \\
\text { (central tumor) }\end{array}$ & $\begin{array}{l}0.367(0.210- \\
0.641)\end{array}$ & $<0.001$ & $\begin{array}{l}0.307(0.171- \\
0.552)\end{array}$ & $<0.001$ & & $H R(95 \% C l)$ & Value $p$ & & \\
\hline $\begin{array}{l}\text { Tumor location } \\
\text { (right lobe) }\end{array}$ & - & - & - & - & $\begin{array}{c}\text { The prognostic } \\
\text { value on SCC } \\
\text { score }^{c}\end{array}$ & & $<0.001$ & & \\
\hline $\begin{array}{l}\text { Poor differentia- } \\
\text { tion }\end{array}$ & - & - & - & - & $\mathrm{SCC}=0$ & Reference & & & \\
\hline $\begin{array}{l}\text { Preoperative } \\
\text { CA19-9>27 } \\
\text { U/mL }\end{array}$ & - & - & - & - & $\mathrm{SCC}=1$ & $\begin{array}{l}0.296(0.153- \\
0.571)\end{array}$ & $<0.001$ & & \\
\hline $\begin{array}{l}\text { Preoperative } \\
\quad \text { CEA }>5 \mathrm{ng} / \mathrm{mL}\end{array}$ & $\begin{array}{l}2.486(1.305- \\
4.734)\end{array}$ & 0.006 & $\begin{array}{l}2.234(1.164- \\
4.287)\end{array}$ & 0.016 & $\mathrm{SCC}=2$ & $\begin{array}{l}0.270(0.133- \\
0.549)\end{array}$ & $<0.001$ & & \\
\hline
\end{tabular}

a To prevent colinearity, RDW-SD was included in the multivariate analysis of Model 1, and RDW-CV was included in the multivariate analysis of Model 2, respectively

b The median operation time and the median blood loss were chosen as the cut-off point

c Because the SCC score was based on the RDW-SD and RDW-CV, the multivariate analysis of prognostic value of SCC score included factors with a $P<0.1$ in univariate analysis exclude of the RDW-SD and RDW-CV

significance for predicting survival. In general, although RDW can predict the prognosis of ICC patients to some extent, its predictions seem to contradict the conclusions of mainstream studies that have shown that RDW value is an independent risk factor for overall survival in patients with $\mathrm{HCC}$, endometrial cancer and prostate cancer in a multivariate analysis $[18,32,33]$. However, there are also studies that show that RDW was not an independent predictor of cancer-specific survival (CSS) or OS in other cancers $[24,34]$. These controversial conclusions led us to re-examine the value of RDW in predicting tumor prognosis and reflecting the heterogeneity among different cancer species.

According to current research evidence, the mechanisms for the poor survival of cancers are not fully understood, are very likely multifactorial, and include inflammation, oxidative stress, and malnutrition [3537]. However, the biological meaning of RDW increase remains largely unknown in spite of several explanations that might indicate the elevated RDW levels. RDW is 
Table 4 Prognostic factors for DFS for ICC patients in Univariate analysis

\begin{tabular}{|c|c|c|c|c|c|}
\hline \multirow[t]{2}{*}{ Factor } & \multicolumn{2}{|l|}{ Univariate analysis } & \multirow[t]{2}{*}{ Factor } & \multicolumn{2}{|l|}{ Univariate analysis } \\
\hline & $\mathrm{HR}(95 \% \mathrm{Cl})$ & Value $p$ & & $\mathrm{HR}(95 \% \mathrm{Cl})$ & Value $p$ \\
\hline Age $\geq 60$ years & $0.797(0.541-1.174)$ & 0.251 & Preoperative CEA $>5 \mathrm{ng} / \mathrm{mL}$ & $2.210(1.442-3.386)$ & $<0.001$ \\
\hline Male & $1.119(0.764-1.640)$ & 0.563 & RDW-SD $>40.2 \mathrm{fl}$ & $0.681(0.459-1.011)$ & 0.047 \\
\hline $\mathrm{BMI} \geq 24 \mathrm{~kg} / \mathrm{m}^{2}$ & $1.014(0.689-1.492)$ & 0.945 & RDW-CV $>12.6 \%$ & $0.896(0.608-1.320)$ & 0.579 \\
\hline ASA score 3-4 & $1.352(0.703-2.599)$ & 0.366 & $\mathrm{ALB} \geq 40 \mathrm{~g} / \mathrm{L}$ & $0.744(0.478-1.159)$ & 0.191 \\
\hline Cirrhosis & $1.101(0.743-1.632)$ & 0.630 & $\mathrm{TBIL}>21 \mathrm{umol} / \mathrm{L}$ & $0.912(0.488-1.703)$ & 0.772 \\
\hline $\operatorname{HBsAg}(+)$ & $1.193(0.765-1.858)$ & 0.436 & $\mathrm{AST}>40 \mathrm{U} / \mathrm{L}$ & $1.606(0.898-2.873)$ & 0.111 \\
\hline T3-T4 stage & $1.711(1.100-2.662)$ & 0.017 & $\mathrm{ALT}>50 \mathrm{U} / \mathrm{L}$ & $2.018(1.120-3.634)$ & 0.019 \\
\hline Lymphnode metastasis & & $<0.001$ & Operation time $\geq 230 \mathrm{~min}^{\mathrm{a}}$ & $1.380(0.941-2.022)$ & 0.099 \\
\hline Undissected lymph node & Reference & & Blood loss $\geq 300 \mathrm{ml}^{\mathrm{a}}$ & $1.710(1.149-2.546)$ & 0.008 \\
\hline Negative lymph node & $1.114(0.685-1.811)$ & 0.664 & Major liver resection & $1.402(0.906-2.171)$ & 0.129 \\
\hline Positive lymph node & $2.713(1.591-4.627)$ & $<0.001$ & Post-operative Complications & $0.998(0.674-1.477)$ & 0.991 \\
\hline Tumor size $\geq 5 \mathrm{~cm}$ & $1.285(0.877-1.884)$ & 0.199 & Preoperative therapy & $1.207(0.587-2.484)$ & 0.609 \\
\hline Multiple tumors & $1.738(1.099-2.751)$ & 0.018 & Adjuvant therapy & $0.887(0.602-1.306)$ & 0.544 \\
\hline Tumor location (central tumor) & $0.702(0.480-1.028)$ & 0.069 & The prognostic value on SCC score & & 0.247 \\
\hline Tumor location (right lobe) & $0.906(0.672-1.222)$ & 0.518 & $\mathrm{SCC}=0$ & Reference & \\
\hline Poor differentiation & $1.443(0.965-2.158)$ & 0.074 & $\mathrm{SCC}=1$ & $0.716(0.447-1.146)$ & 0.164 \\
\hline Preoperative CA19-9>27 U/mL & $1.364(0.875-2.124)$ & 0.170 & $\mathrm{SCC}=2$ & $0.698(0.438-1.113)$ & 0.131 \\
\hline
\end{tabular}

a The median operation time and the median blood loss were chosen as the cut-off point

positively correlated with widely used plasma inflammatory markers, such as C-reactive protein (CRP) $[38,39]$ and blood sedimentation rate (ESR) [40], and is considered to be an inflammatory marker in cancer patients. Various inflammatory factors affect erythropoiesis through the production of erythropoietin (EPO), the inhibition of erythro-progenitor cells, and the reduction of iron release. In conclusion, the hypothesis that RDW can reflect the inflammatory state of cancer is reasonable. Second, malnutrition is another characteristic of cancer due to loss of appetite and weight loss and can lead to deficiencies in minerals and vitamins such as iron, folic acid and vitamin B12, which can also lead to changes in RDW values. In summary, high RDW levels are a good indicator of chronic inflammation and malnutrition in cancer patients. However, it is still controversial whether the prognosis of tumor patients can be predicted in a real-world setting. Studies point to evidence that tumors mainly occur in middle-aged and elderly populations, and the prevalence of anemia and malnutrition in elderly patients is relatively high, which may lead to elevated RDW values due to other aspects, thereby reducing the prognostic significance of this parameter for tumors [20]. Similarly, the investigators demonstrated that RDW was no longer associated with OS or DFS in patients with esophageal squamous cells after adjusting the correlation index [41]. Another study of esophageal cancer reached the same conclusion [42]. Such differences in outcome may be related to the selected population. The inclusion criteria for patients in this study included no association with chronic pneumonia or other diseases that affect RDW value, thus excluding the influence of these diseases on RDW and the analysis results. Most of the patients in this study had RDW values within the normal range, while other studies, especially those investigating blood-related diseases, did not exclude patients with a large number of RDW abnormalities, so different results may appear. In addition, there was heterogeneity among different cancer species, and the predictive value of RDW may not be applicable to all disease species. Among the differences in statistical methods, the heterogeneity of RDW in different studies led to different methods for selecting cut-off values. The majority of the studies used ROC analysis to define the cut-off values. In some studies, the median was used as the cut-off point, and the above two methods were used to select a cut-off point value of $90 \%$ with an applied cut-off value between 13 and 15\% [43]. In this study, X-tile analysis was used for the first time to obtain a cut-off point value of $12.6 \%$ by fitting the relationship between prognosis and RDW. The differences in statistical methods led to different research results.

There are also limitations in this study. First, only preoperative RDW values were included in this study, but the clinical value of postoperative RDW remains unclear and may dynamically represent changes in the balance between systemic inflammatory responses and immune responses after treatment. Second, this study 
revealed that pre-operative CA19-9 level was not significantly associated with survival, the reason of which was that some patients with concomitant cholangitis (complicated by symptoms such as epigastric pain, hyperleukocytosis, or fever) were included in this study. Some studies have shown that preoperative cholangitis may affect on the value of CA19-9 [44, 45]. In future studies, in order to remove the influence of cholangitis on CA19-9 or other markers, we would strictly include the criteria and exclude this subset of patients. Finally, the data were collected retrospectively from a single center; therefore, our results may be potentially biased and inaccurate.

\section{Conclusions}

In conclusion, our results indicated that elevated preoperative RDW values within a certain range do not indicate a worse prognosis; more meaningful results were obtained: we obtained the opposite conclusion as that in the literature. However, the significance of RDW in predicting the prognosis of ICC needs to be confirmed by larger, prospective, randomized studies.

\begin{abstract}
Abbreviations
ICC: Intrahepatic cholangiocarcinoma; OS: Overall survival; PLT: Platelet count; NLR: Neutrophil-lymphocyte ratio; PLR: Platelet-lymphocyte ratio; RDW: Red blood cell distribution width; RDW-SD: Red blood cell distribution widthstandard deviation; RDW-CV: Red blood cell distribution width-coefficient of variation; SCC: RDW-SD combined with RDW-CV; HCC: Hepatocellular carcinoma; CA19-9: Carbohydrate antigen 19-9; CEA: Carcinoembryonic antigen; AFP: Alpha fetoprotein; MRI: Magnetic resonance imaging; CT: Computed tomography; MVI: Microvascular invasion; ALB: Albumin; TBIL: Total bilirubin; AST: Aspartate aminotransferase; ALT: Alanine aminotransferase; TACE: Transarterial chemoembolization; HBsAg: Hepatitis B surface antigen; DFS: Disease-free survival; CRP: C-reactive protein; ESR: Blood sedimentation rate; EPO: Erythropoietin.
\end{abstract}

\section{Acknowledgements}

We gratefully acknowledge all staff members of Department of Hepatobiliary Surgery, National Cancer Center/National Clinical Research Center for Cancer/ Cancer Hospital, Chinese Academy of Medical Sciences and Peking Union Medical College, Beijing, China, for their help and cooperation.

\section{Authors' contributions}

$X \mathrm{~L}$ and $\mathrm{QC}$ are the main authors of manuscript and have made substantial contributions to the conception and design of study. XB, JZ, ZL, JZ, ZH, YZ and $\mathrm{RM}$ have been involved in collection and analysis of the data, $\mathrm{HZ}$ and JC gave final approval and revised of the manuscript. All authors read and approved the final manuscript.

\section{Funding}

This work was supported by the National Capital Health Research and Development of Special (No. 2018-1-4021) and the National Science and Technology Major Project (No. 2018ZX10723204). Principal Investigator: Jianqiang Cai. Members of the funding body participated in the design of the study and data analysis. And the funding body will cover the publication charge.

\section{Availability of data and materials}

The data that support the findings of this study are available from the corresponding author upon reasonable request. Emails could be sent to the address below to obtain the shared data: Ixc_pumc@126.com

\section{Ethics approval and consent to participate}

The research was in compliance with the Declaration of Helsinki. Ethical approval was obtained from the Institutional Review Board of the Cancer Hospital, Chinese Academy of Medical Sciences (ID: NCC2019C-016) and the necessity for informed consent was waived.

\section{Consent for publication}

Not applicable.

\section{Competing interests}

The authors declare that they have no competing interests.

Received: 18 June 2020 Accepted: 9 February 2021

Published online: 01 March 2021

\section{References}

1. Esnaola NF, Meyer JE, Karachristos A, et al. Evaluation and management of intrahepatic and extrahepatic cholangiocarcinoma. Cancer. 2016;122(9):1349-69.

2. Jarnagin WR, Shoup M. Surgical management of cholangiocarcinoma. Semin Liver Dis. 2004;24(2):189-99.

3. Poultsides GA, Zhu AX, Choti MA, et al. Intrahepatic cholangiocarcinoma. Surg Clin North Am. 2010;90(4):817-37.

4. Lafaro KJ, Cosgrove D, Geschwind JF, et al. Multidisciplinary care of patients with intrahepatic cholangiocarcinoma: updates in management. Gastroenterol Res Pract. 2015;2015:860-1.

5. Grivennikov SI, Greten FR, Karin M. Immunity, inflammation, and cancer. Cell. 2010;140(6):883-99.

6. Mantovani A, Allavena P, Sica A, et al. Cancer-related inflammation. Nature. 2008;454(7203):436-44.

7. Deans $C$, Wigmore SJ. Systemic inflammation, cachexia and prognosis in patients with cancer. Curr Opin Clin Nutr Metab Care. 2005;8(3):265-9.

8. Chen Y, Zhang L, Liu WX, et al. Prognostic significance of preoperative anemia, leukocytosis and thrombocytosis in chinese women with epithelial ovarian cancer. Asian Pac J Cancer Prev: APJCP. 2015;16(3):933-9.

9. Obermair A, Petru E, Windbichler G, et al. Significance of pretreatment serum hemoglobin and survival in epithelial ovarian cancer. Oncol Rep. 2000;7(3):639-44.

10. Templeton AJ, Ace O, McNamara MG, et al. Prognostic role of platelet to lymphocyte ratio in solid tumors: a systematic review and meta-analysis. Cancer Epidemiol Biomarker Prev. 2014;23(7):1204-12.

11. Li J, Jiang R, Liu W-S, et al. A large cohort study reveals the association of elevated peripheral blood lymphocyte-to-monocyte ratio with favorable prognosis in nasopharyngeal carcinoma. PLoS ONE. 2013;8(12):e83069.

12. Zhou $X$, Du Y, Huang Z, et al. Prognostic value of PLR in various cancers: a meta-analysis. PLoS ONE. 2014;9:e101119.

13. Salvagno GL, Sanchis-Gomar F, Picanza A, et al. Red blood cell distribution width: a simple parameter with multiple clinical applications. Crit Rev Clin Lab Sci. 2015;52(2):86-105.

14. Felker GM, Allen $L A$, Pocock $S J$, et al. Red cell distribution width as a novel prognostic marker in heart failure: data from the CHARM Program and the Duke Databank. J Am Coll Cardiol. 2007;50(1):40-7.

15. Montagnana M, Cervellin G, Meschi T, et al. The role of red blood cell distribution width in cardiovascular and thrombotic disorders. Clin Chem Lab Med. 2012;50(4):635-41.

16. Tham T, Bardash Y, Teegala S, et al. The red cell distribution width as a prognostic indicator in upper aerodigestive tract (UADT) cancer: a systematic review and meta-analysis. Am J Otolaryngol. 2018;39(4):453-8.

17. Hu L, Li M, Ding Y, et al. Prognostic value of RDW in cancers: a systematic review and meta-analysis. Oncotarget. 2017;8(9):16027-35.

18. Zhao $T$, Cui L, Li A. The significance of RDW in patients with hepatocellular carcinoma after radical resection. Cancer Biomarkers. 2016;16(4):507-12.

19. Zhu Y, Li JH, Yang J, et al. Inflammation-nutrition scope predicts prognosis of early-stage hepatocellular carcinoma after curative resection. Medicine. 2017;96(39):e8056.

20. Hirahara N, Matsubara T, Kawahara D, et al. Prognostic value of hematological parameters in patients undergoing esophagectomy for esophageal squamous cell carcinoma. Int J Clin Oncol. 2016;21(5):909-19. 
21. Zhang F, Chen Z, Wang P, et al. Combination of platelet count and mean platelet volume (COP-MPV) predicts postoperative prognosis in both resectable early and advanced stage esophageal squamous cell cancer patients. Tumour Biol. 2016a;37(7):9323-31.

22. Ichinose J, Murakawa T, Kawashima M, et al. Prognostic significance of red cell distribution width in elderly patients undergoing resection for nonsmall cell lung cancer. J Thorac Dis. 2016;8(12):3658-66.

23. Wang J, Xie X, Cheng F, et al. Evaluation of pretreatment red cell distribution width in patients with multiple myeloma. Cancer Biomarkers. 2017;20(3):267-72.

24. Shota S, Saito H, Kono Y, et al. Prognostic significance of pre- and postoperative red-cell distribution width in patients with gastric cancer. J Gastrointest Surg. 2019;2:1-8.

25. Camp RL, Dolled-Filhart M, Rimm DL. X-tile: a new bio-informatics tool for biomarker assessment and outcome-based cut-point optimization. Clin Cancer Res. 2004;10(21):7252-9.

26. Salvagno GL, Sanchis-Gomar F, Picanza A, Lippi G. Red blood cell distribution width: a simple parameter with multiple clinical applications. Crit Rev Clin Lab Sci. 2015;52:86-105.

27. Di Somma S, Magrini L, Travaglino F, et al. Opinion paper on innovative approach of biomarkers for infectious diseases and sepsis management in the emergency department. Clin Chem Lab Med. 2013;51:1167-75.

28. Mahmood NA, Mathew J, Kang B, et al. Broadening of the red blood cell distribution width is associated with increased severity of illness in patients with sepsis. Int J Crit IIIn Inj Sci. 2014;4:278-82.

29. Ide S, Toiyama Y, Okugawa Y, et al. Clinical significance of an increased red blood cell distribution width in patients with rectal cancer undergoing chemoradiotherapy followed by surgery. Surg Today. 2020;50:551-9.

30. Ma W, Mao S, Bao M, et al. Prognostic significance of red cell distribution width in bladder cancer. Transl Androl Urol. 2020;9:295-302.

31. Pedrazzani C, Tripepi M, Turri G, et al. Prognostic value of red cell distribution width (RDW) in colorectal cancer. Results from a single-center cohort on 591 patients. Sci Rep. 2020;10:1072.

32. Kemal Y, Demirag G, Bas B, et al. The value of red blood cell distribution width in endometrial cancer. Clin Chem Lab Med (CCLM). 2015;53(5):823-7.

33. Albayrak S, Zengin K, Tanik S, et al. Red cell distribution width as a predictor of prostate cancer progression. Asian Pac J Cancer Prev: APJCP. 2014;15(18):7781-4.

34. Alvin $\mathrm{L}$, Han $\mathrm{L}$, Hong $H \mathrm{H}$, et al. Prognostic significance of inflammationassociated blood cell markers in nonmetastatic clear cell renal cell carcinoma. Genitourinary Cancer. 2019;12(11):1-10.
35. Ferrucci L, Guralnik JM, Woodman RC, et al. Proinflammatory state and circulating erythropoietin in persons with and without anemia. Am J Med. 2005;118(11):1288.e11-1288.e19.

36. Hanahan D, Weinberg RA. Hallmarks of cancer: the next generation. Cell. 2011;144(5):646-74.

37. Semba RD, Patel KV, Ferrucci L, et al. Serum antioxidants and inflammation predict red cell distribution width in older women: the women's health and aging study I. Clin Nutr. 2010;29(5):600-4.

38. Wan GX, Chen P, Cai XJ, et al. Elevated red cell distribution width contributes to a poor prognosis in patients with esophageal carcinoma. Clin Chim Acta. 2016;452:199-203.

39. Perisa V, Zibar L, Sincic-Petricevic J, et al. Red blood cell distribution width as a simple negative prognostic factor in patients with diffuse large B-cell lymphoma: a retrospective study. Croat Med J. 2015;56(4):334-43.

40. Meng S, Ma Z, Lu C, Liu H, Tu H, Zhang W, et al. Prognostic value of elevated red blood cell distribution width in chinese patients with multiple myeloma. Ann Clin Lab Sci. 2017;47(3):282-90.

41. Zhang F, Chen Z, Wang P, et al. Combination of platelet count and mean platelet volume (COP-MPV) predicts postoperative prognosis in both resectable early and advanced stage esophageal squamous cell cancer patients. Tumor Biol. 2016b. https://doi.org/10.1007/s13277-015-4774-3.

42. Sun $P$, Zhang F, Chen $C$, et al. The ratio of hemoglobin to red cell distribution width as a novel prognostic parameter in esophageal squamous cell carcinoma: a retrospective study from southern China. Oncotarget. 2016;7(27):42650-60.

43. Wang P-F, Song S-Y, Guo H, et al. Prognostic role of pretreatment red blood cell distribution width in patients with cancer: a meta-analysis of 49 studies. J Cancer. 2019;10(18):4305-17.

44. Sheen-Chen SM, Sun CK, Liu YW, et al. Extremely elevated CA19-9 in acute cholangitis. Dig Dis Sci. 2007;52(11):3140-2.

45. Yuksel BC, Yildiz Y, Ozturk B, et al. Serum tumor marker CA19-9 in the follow-up of patients with cystic echinococcosis. Am J Surg. 2008;195(4):452-6.

\section{Publisher's Note}

Springer Nature remains neutral with regard to jurisdictional claims in published maps and institutional affiliations.

Ready to submit your research? Choose BMC and benefit from:

- fast, convenient online submission

- thorough peer review by experienced researchers in your field

- rapid publication on acceptance

- support for research data, including large and complex data types

- gold Open Access which fosters wider collaboration and increased citations

- maximum visibility for your research: over $100 \mathrm{M}$ website views per year

At BMC, research is always in progress.

Learn more biomedcentral.com/submissions 